\title{
Explant technique for the isolation of stem cell from the dental pulp of permanent teeth
}

\author{
Eduarda GZ Centeno ${ }^{*}$, Camila P Ferrúa, Fernanda Nedel, Sandra BC Tarquinio, Flávio F Demarco \\ From 5th Congress of the Brazilian Biotechnology Society (SBBIOTEC) \\ Florianópolis, Brazil. 10-14 November 2013
}

\begin{abstract}
Background
Currently, the use of stem cells from permanent (DPSCs) and deciduous teeth (SHEDs) has enabled many therapeutic advances. Despite numerous sources of stem cells, DPSCs and SHEDs have shown several advantages, since the isolation method is noninvasive and cells present rapid expansion in vitro [1]. DPSCs have shown the capacity to form a dentin-pulp like complex. Due to its high osteogenic potential, these cells have been applied around dental implants in order to form new bone tissue [2-4]. Given the clinical relevance in developing research towards DPSCs, this study aimed to isolate stem cells from dental pulp tissue using the explant technique.
\end{abstract}

\section{Methods}

This study was approved by the Ethics Committee in Research of the Faculty of Dentistry, Federal University of Pelotas (FO-UFPel). Third molars were collected immediately after extraction, stored in culture medium and kept at low temperature to be transported to the laboratory. Fracture lines were made in the teeth with a chisel, in order to expose the pulp. The tissue was removed from the pulp chamber and fragmented into explants which were placed in 6 well plates and DMEM/Ham F12 medium with 15\% of FBS (Hyclone), $1 \%$ of antibiotic and $1 \%$ of aminoacids non essential (Gibco) was added. The plates were incubated, for 14 days and analyzed using an inverted microscope.

The viability of the DPSCs was determined by measuring the reduction of soluble MTT [3-(4,5-dimethylthiazol2-yl)-2,5- diphenyltetrazolium bromide] to water-insoluble formazan [4]. Cells in the $3^{\circ}, 4^{\circ}, 5^{\circ}$ and $6^{\circ}$ passages were used [5]. Briefly, cells were seed at a density of 2500 cells/ $\mathrm{cm} 2$ and 1000 cells $/ \mathrm{cm} 2$ and incubated at $37^{\circ} \mathrm{C}$ in a humidified atmosphere of 5\% CO2/95\% air for 1, 3, 5 and 7 days. After incubation the medium was removed and $180 \mu \mathrm{L}$ of DMEM/Ham F12 and $20 \mu \mathrm{L}$ MTT (5 mg MTT/ $\mathrm{mL}$ solution) was added to each well. The plates were incubated for an additional $4 \mathrm{~h}$ and the medium was discarded. $200 \mu \mathrm{L}$ of DMSO was added to each well, and the formazan was solubilized on a shaker for $5 \mathrm{~min}$ at $100 \mathrm{rpm}$. The absorbance of each well was read on a microplate reader (Thermo TP-plate reader, Thermo Fisher Scientific, Waltham, MA, USA) at a wavelength of $450 \mathrm{~nm}$. All observations were performed in triplicate and validated by at least two independent experiments.

\section{Results and conclusion}

Cell migration, morphology and proliferative results were adequate and compatible with DPSC isolation. Cell presented a fusiform morphology and an elongated cytoplasm, indicating high cell metabolism. The cellular viability assay showed that cultures seeded with 2500 cells $/ \mathrm{cm}^{2}$ exhibit higher values of absorbance compared to 1000 cells $/ \mathrm{cm}^{2}$ cell density. In addition, the increase in cell incubation time improved absorbance values. In summary, after 14 days of explant culture, there was an adequate cell migration and proliferation, indicating the isolation of DPSCs using the explant technique.

\section{Acknowledgements \\ MCTI / CNPq / MS-SCTIE - Decit N. 36/2012.}

Published: 1 October 2014

\section{References}

1. da Costa AM, Bueno DF, Kerkis I, Kerkis A, Fanganiello RD, Cerruti H, Alonso N, Passos-Bueno MR: Reconstruction of large cranial defects in nonimmunosuppressed experimental design with human dental pulp stem cells. J Craniofac Surg 2008, 19:204-210. 
2. Ito K, Yamada Y, Nakamura S, Ueda M: Osteogenic potential of effective bone engineering using dental pulp stem cells, bone marrow stem cells, and periosteal cells for osseointegration of dental implants. Int $J$ Oral Maxillofac Implants 2011, 26:947-954.

3. Nedel F, André Dde A, de Oliveira IO, Cordeiro MM, Casagrande L, Tarquinio SB, Nor JE, Demarco FF: Stem cells: therapeutic potential in dentistry. J Contemp Dent Pract 2009, 10(4):90-96.

4. Nedel F, Campos VF, Alves D, McBride AJ, Dellagostin OA, Collares T, Savegnago L, Seixas FK: Substituted diaryldiselenides: cytotoxic and apoptotic effect in human colon adenocarcinoma cells. Life Sci 2012, 24:345-352.

5. Bernardi L, Luisi SB, Fernandes R, Dalberto TP, Valentim L, Chies JAB, Fossati ACM: Pranke: The isolation of stem cells from human deciduous teeth pulp is related to the physiological process of resorption. J Endod 2011, 37:973-979.

\section{doi:10.1186/1753-6561-8-S4-P66}

Cite this article as: Centeno et al:: Explant technique for the isolation of stem cell from the dental pulp of permanent teeth. BMC Proceedings 2014 8(Suppl 4):P66.

\section{Submit your next manuscript to BioMed Central and take full advantage of:}

- Convenient online submission

- Thorough peer review

- No space constraints or color figure charges

- Immediate publication on acceptance

- Inclusion in PubMed, CAS, Scopus and Google Scholar

- Research which is freely available for redistribution

Submit your manuscript at www.biomedcentral.com/submit 